\title{
The birth of the Rheic Ocean - Early Palaeozoic subsidence patterns and subsequent tectonic plate scenarios
}

\author{
Jürgen F. von Raumer ${ }^{\mathrm{a}, *}$, Gérard M. Stampfli ${ }^{\mathrm{b}}$ \\ a Department de Géosciences, Université de Fribourg, Suisse, Switzerland \\ b Géologie-Paléontologie, Université de Lausanne, Suisse, Switzerland
}

Keywords:

Early Palaeozoic

Subsidence

Extensional crust

Rheic Ocean

Gondwana margin

Palaeotethys

\begin{abstract}
A B S T R A C T
New plate-tectonic reconstructions of the Gondwana margin suggest that the location of Gondwana-derived terranes should not only be guided by the models, but should also consider the possible detrital input from some Asian blocks (Hunia), supposed to have been located along the Cambrian Gondwana margin, and accreted in the Silurian to the North-Chinese block. Consequently, the Gondwana margin has to be subdivided into a more western domain, where the future Avalonian blocks will be separated from Gondwana by the opening Rheic Ocean, whereas in its eastern continuation, hosting the future basement areas of Central Europe, different periods of crustal extension should be distinguished. Instead of applying a rather cylindrical model, it is supposed that crustal extension follows a much more complex pattern, where local back-arcs or intra-continental rifts are involved.

Guided by the age data of magmatic rocks and the pattern of subsidence curves, the following extensional events can be distinguished:

- During the early to middle Cambrian, a back-arc setting guided the evolution at the Gondwana margin. Contemporaneous intra-continental rift basins developed at other places related to a general post-PanAfrican extensional phase affecting Africa

- Upper Cambrian formation of oceanic crust is manifested in the Chamrousse area, and may have lateral cryptic relics preserved in other places. This is regarded as the oceanisation of some marginal basins in a context of back-arc rifting. These basins were closed in a mid-Ordovician tectonic phase, related to the subduction of buoyant material (mid-ocean ridge?)

- Since the Early Ordovician, a new phase of extension is observed, accompanied by a large-scale volcanic activity, erosion of the rift shoulders generated detritus (Armorican Quartzite) and the rift basins collected detrital zircons from a wide hinterland. This phase heralded the opening of Palaeotethys, but it failed due to the Silurian collision (Eo-Variscan phase) of an intra-oceanic arc with the Gondwana margin.
\end{abstract}

During this time period, at the eastern wing of the Gondwana margin begins the drift of the future Hunia microcontinents, through the opening of an eastern prolongation of the already existing Rheic Ocean. The passive margin of the remaining Gondwana was composed of the Galatian superterranes, constituents of the future Variscan basement areas. Remaining under the influence of crustal extension, they will start their drift to Laurussia since the earliest Devonian during the opening of the Palaeotethys Ocean.

\section{Introduction}

Great advances in reconstructing the birth and life of the Rheic Ocean have been made during the last years, leading to scenarios showing the evolution of the Gondwana margin from the Neoproterozoic to the Ordovician. A model of Neoproterozoic-Cambrian

\footnotetext{
* Corresponding author.

E-mail addresses: Juergen.vonRaumer@unifr.ch (J.F. von Raumer), Gerard.Stampfli@unil.ch (G.M. Stampfli).
}

cordillera was applied to the Avalonian part of the Gondwana margin (Nance et al., 2002), completed by new insight (Murphy et al., 2006; Arenas et al., 2007b; Linnemann et al., 2007). Equally in our scenario, after the Cadomian orogenic events, many of the Gondwana-derived microcontinents resided in a convergent margin setting (Fig. 1), with an oceanic domain (called Prototethys in the more eastern parts, Iapetus or Tornquist Ocean for the more western parts) subducting under Gondwana. Relics of a Neoproterozoic-Cambrian arc can be identified from the Ossa Morena (Bandres et al., 2002, Sánchez García et al., 2003, Pereira et al., 2007) and the Central Iberian Zone (Fernández-Suárez et al., 2000; Rodríguez Alonso, 2004) in the west, 


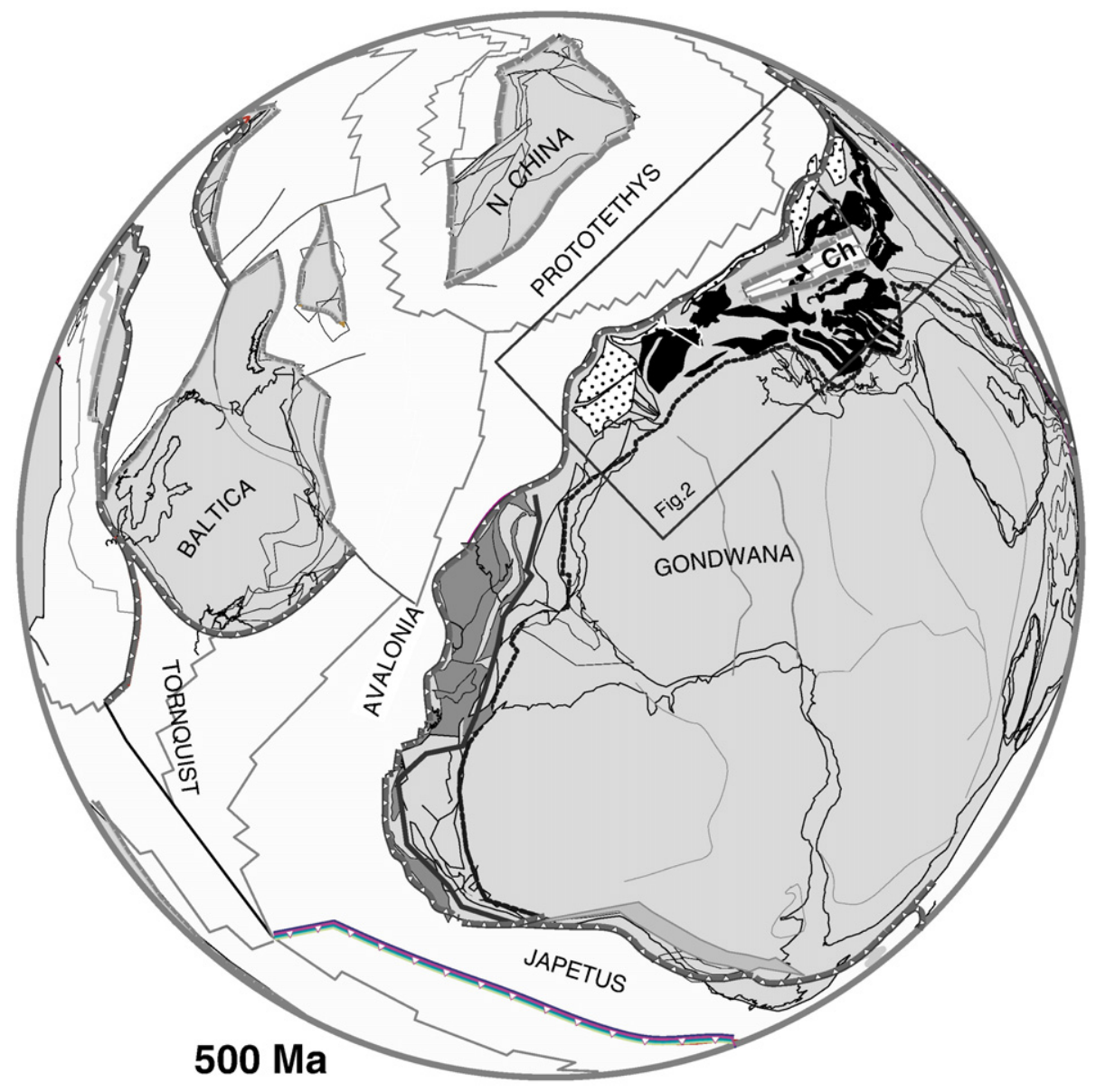

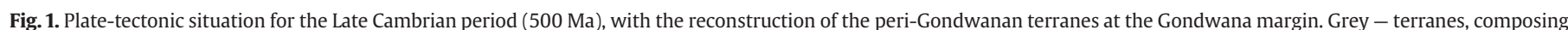

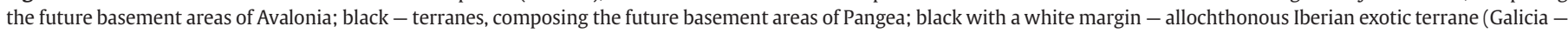

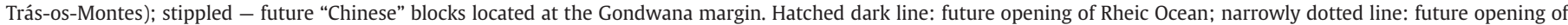

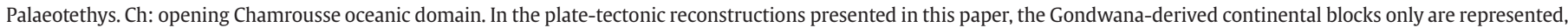
assuming that they carry in most cases their contemporaneous sedimentary cover.

across the Black Forest (Chen et al., 2000), the Saxothuringian units (Kemnitz et al., 2002), and the Bohemian Massif (Zulauf et al., 1999; Stipska et al., 2001; Dörr et al., 2002) to the Central Alps (Lower Penninic nappes, Ticino, Schaltegger et al., 2002; Austro-Alpine units, Silvretta, Schaltegger et al., 1997), the Eastern Alps (Schulz et al., 2004) and Western Carpathes (Putis et al., 2008), and the Western Pontides (Ustaömer et al., 2005) in the East.

Many sedimentological environments would have existed in the convergent margin, including fore-arc basins with deep-sea trenches, intra-arc, back-arc and rift basin settings. The present-day Neoproterozoic to Cambrian cover-sequences, well preserved in the Moroccan Anti-Atlas region, may represent the low-grade counterparts of the mostly highly metamorphosed lithologies widely distributed in the Gondwana-derived continental blocks, which were transformed during the Variscan and/or Alpine orogenies (von Raumer et al., 2003). All of these areas would have provided a wide variety of potential ecological niches, which would have encouraged the progressive evolutions of their biotas. Published lithostratigraphic data from different regions allow us to assess the subsidence history and tectonic evolution of distinct areas along the Gondwana margin. The Early Cambrian represents a time period when major plate interactions initiated a new plate-tectonic configuration. Consequently, a short review of this Cambrian plate-tectonic evolution may define the problems to be resolved. It is the aim of this paper to introduce reconstructed subsidence patterns to learn more about the geodynamic evolution at the Gondwana margin, and to introduce the problems emerging around the existence and opening of Palaeotethys.

\section{Reconstructions - their philosophy}

Plate-tectonic concept have been systematically applied to our palinspastic models, moving away from pure continental drift models, not constrained by plate limits, to produce a model which finally is more and more self-constrained. In this approach (first explained in Stampfli and Borel, 2004) inter-dependent reconstructions are created from the past to the present. Except during collisions, plates are moved step by step, as single rigid entities. The only evolving elements are the plate boundaries, which are preserved and follow a consistent geodynamic evolution through time and an interconnected network through space. Hence, lithospheric plates are constructed by adding/ removing oceanic material (symbolized by synthetic isochrones) to major continents and terranes. In the last years we changed our tools and moved into GIS softwares and built a geodynamic database to support the reconstructions, and the model was, and still is, extended to the whole globe. An example of this new approach can be found in Ferrari et al. (2008). The plate-tectonic reconstructions presented here (500 Ma, $460 \mathrm{Ma}, 394 \mathrm{Ma}$ ) are part of a series starting at $600 \mathrm{Ma}$ and ending at $20 \mathrm{Ma}$ done at a global scale with a reconstruction every $15 \mathrm{Ma}$ in average. The corresponding palinspastic cross-sections (Fig. 7) are not fixed to a terrane or continent, they present the 
characteristic situation for a given time in a 2D model. This is a totally non-fixist approach, in which terranes are always moving in and out of such cross-sections. The basic principle here is that the present-day juxtaposition of terranes does not represent, in most cases, the original relationships of the terranes. The relative motion of many Variscan terranes is measured in thousands of kilometers.

\section{The Cambrian period}

Palaeogeographic analyses for the Cambrian (Courjault-Radé et al., 1992; Alvaro et al., 2003) show an extensive distribution of epicontinental sediments, which have been previously interpreted as having been deposited on the rifting Gondwana margin (Franke, 1992). Related extensional faults were discussed by Zulauf et al. (1997), and the deposition of Cambrian epicontinental sediments was accompanied by contemporaneous rifting (Liñan and Quesada, 1990) and volcanic activity (Extebarria et al., 2006). Robardet et al. (1994), Patoĉka and Storch (2004), and Silva and Pereira (2004) discussed the presence of marine to intra-cratonic basins, long rivers recycling the products of erosion of the cratonic areas (Zeh et al., 2001). The resulting sediments and their chemical composition recorded the increasing erosion of pre-existing crust with a considerable geochemical homogeneity of the shaly components (Ugidos et al., 2003). A maximum depositional age of c. $600 \mathrm{Ma}$ for the detrital sediments is constrained by the youngest detrital zircons (Schaltegger and Gebauer, 1999; Thöni, 1999) in the Alpine pre-Mesozoic basement. Such zircon assemblages may also be represented in the "pre-orogenic age populations" (Martínez Catalán et al., 2004) from the Central Iberian domain. Although interpreted to represent uninterrupted erosion, such populations may in fact have resulted from several erosional events. This includes complete reworking during the uplift of rift shoulders and formation of younger syn-rift sediments during and after the Ordovician, during which locally thousands of meters of detrital sediments were deposited, representing the reworking of the large hinterland exposed near the rift systems.

In the general situation for the Late Cambrian (Fig. 1), most of the basement areas known from Central Europe were located at the Gondwana margin (Stampfli et al., 2006). In this model, the future Variscan blocks now found from Central America to the Caucasus, have been spread along the Gondwana margin, representing a future ribbon-like terrane of more than $10,000 \mathrm{~km}$ long. We formerly called this terrane the Hun superterrane (Stampfli et al., 2002), however, we now reserved the term Hunia for terranes that were accreted to the North China block, and we now refer to this ribbon continent as Greater Galatian superterrane (its European part being called Galatian terrane s.str.).

\section{The subsidence patterns}

We cannot repeat all the data published about the CambrianOrdovician sedimentary evolution at the Gondwana margin. The published lithostratigraphic data (references, see Figs. 3,4, and 6) allow us to illustrate the subsidence history and, hence, to constrain the tectonic evolution of Early Palaeozoic basins along the Gondwana margin. In an earlier paper (von Raumer et al., 2006) the four main subsidence patterns of the Iberian Massif were discussed specifically, showing a contemporaneous evolution of sedimentary troughs occupying, at present-day, distinct tectonostratigraphic units (Ossa Morena, Central Iberian, West Asturian Leonese and Cantabrian Zones).

\subsection{Lower Cambrian}

In the larger European frame, since the earliest Cambrian (540$510 \mathrm{Ma}$ ), strong subsidence is seen as the expression of an extensional setting at the Gondwana margin, either related to subduction and roll- back of Prototethys or to contemporaneous intra-continental rifting related to a post-Pan-African extension. Such subsidence patterns are documented (Fig. 3) from the Anti-Atlas, Ossa Morena, Central Iberian; West Asturian Leonese, and Cantabrian Zones, and for the Montagne Noire, and the Barrandian as well. Early Cambrian is identified in the Pyrenean and Saxothuringian Zones, and it is supposed that Cambrian sediments were present (at least partially) in all the domains (comp. Fig. 4). Striking similarities in the subsidence patterns exist for the Ossa Morena and Anti-Atlas areas, and again, subsidence is comparable in the Central Iberian and the Barrandian domains.

\subsection{Upper Cambrian}

After the earliest rifting period, a new large-scale tectonic event is marked by the Upper Cambrian formation of oceanic crust manifested in the Chamrousse area (comp. Fig. 2), which may have lateral cryptic relics preserved in other places (see below). This event can be regarded as the oceanisation of some marginal basins in a context of back-arc rifting (see discussion below) due to increased roll-back of Prototethys. A corresponding stronger subsidence is observed for the West Asturian Leonese, and the Barrandian areas. Is the opening of the Chamrousse a time equivalent event to the already initial opening of the Rheic Ocean to the west?

\subsection{Ordovician}

Starting in the Lower Ordovician (Fig. 4), a new phase of subsidence was recorded by the sediments of the Central Iberian Zone (Fig. 4), accompanied by a large-scale volcanic activity. Although the subsidence pattern of the Cantabrian zone remains rather regular, Ordovician volcanics (comp. Fig. 4) indicate the Ordovician rifting event in this zone (Gutiérrez-Marco and Bernárdez, 2003; GutiérrezAlonso et al., 2007). Contemporaneously, in the subsidence patterns of the Saxothuringian and the Barrandian areas (Fig. 3), a striking thermal uplift is documented. Although illustrating only burial, the patterns for the Southern Brittany area (Robardet et al., 1994) correspond narrowly to the evolution of the western Central Iberian subsidence curve.

Interestingly, tectonic subsidence curves for the Lower Palaeozoic from Eastern Avalonia (Prigmore et al., 1997) and a cumulative thickness curve from the Brabant massif (Verniers et al., 2002) underline an early rifting period during the Lower Cambrian with subsequent periods of more rapid subsidence during the Late Cambrian/Tremadoc and Arenig-Llanvirn periods. Even in the easternmost portions of the margin prolongation (East Alborz, High Lahul, Central Taurus) the initial subsidence patterns for the CambroOrdovician (Stampfli et al., 2001) show the fingerprints of the midCambrian rifting and continued Ordovician subsidence. The subsequent rapid subsidence records the opening Palaeotethys rift system in these regions, and in the Pyrenees and Carnic Alps (Fig. 4).

\section{The Early Palaeozoic plate-tectonic evolution - a discussion}

Strike-slip models (Murphy and Nance, 1989) may explain the different scenarios at the Gondwana margin. During oblique convergence, plume-like structures may have existed beneath pull apart (e.g. in the Bohemian Massif, Floyd et al., 2000) or isolated rift basins. Detrital sediments record the maximum subsidence and were coeval with rift volcanism in longitudinal continuity, for example, in the Sudetes (Kryza et al., 2007), in the Bohemian Massif (Kachlik and Patoĉka, 1996; Zulauf et al., 1997), in the Saxothuringian domain (Linnemann et al., 1998; Kemnitz et al., 2002), in the Ossa Morena Zone (Sánchez García et al., 2003) or at the limits between Ossa Morena and Central Iberian Zones (Rodríguez Alonso et al., 2004).

New plate-tectonic reconstructions (Fig. 1) of the Gondwana margin suggest that the location of Gondwana-derived terranes should not 


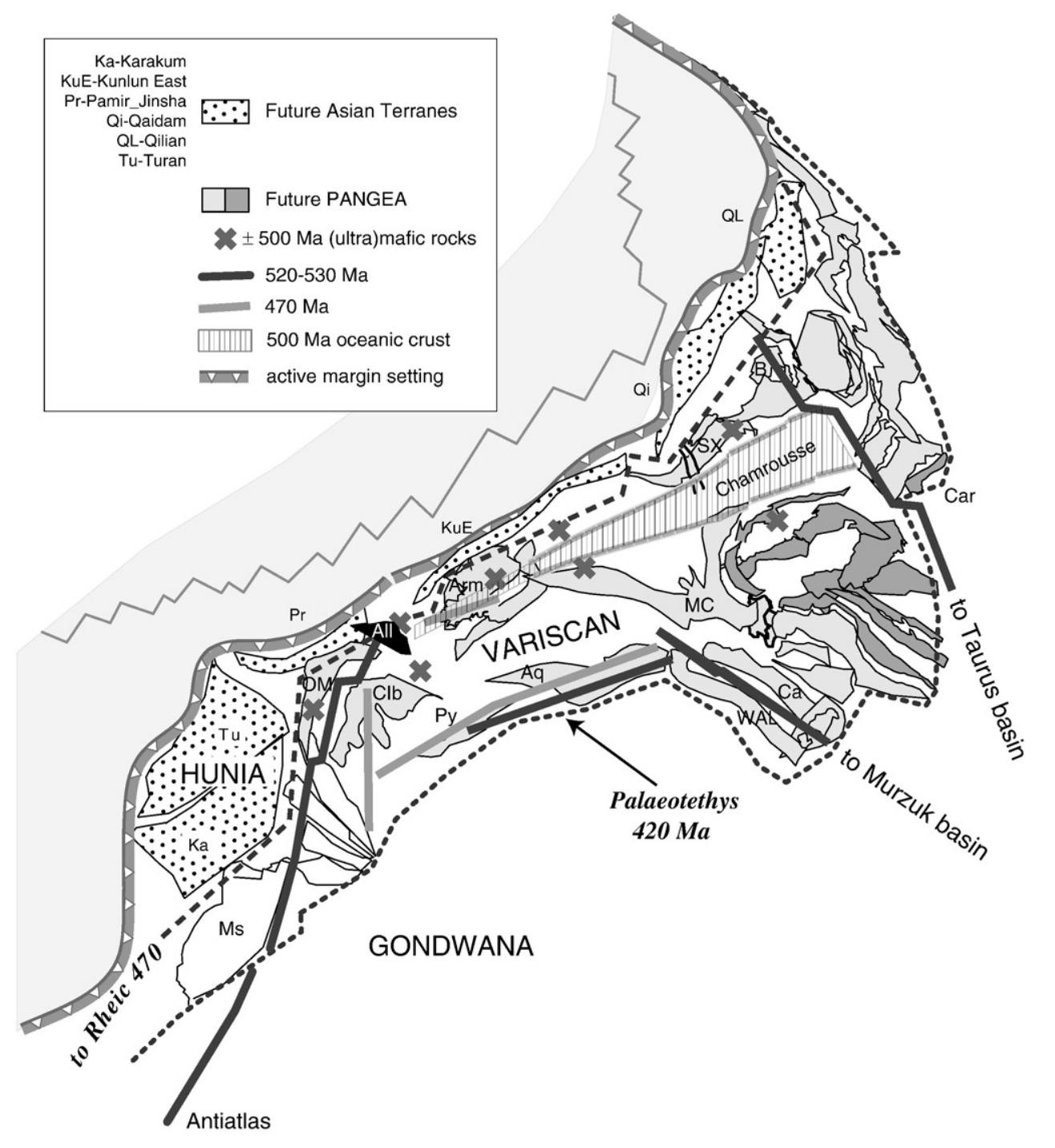

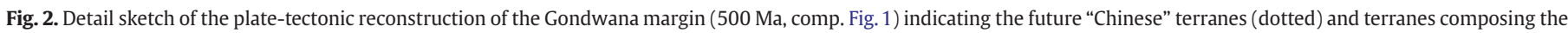

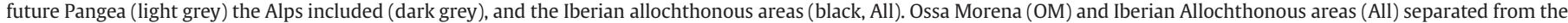

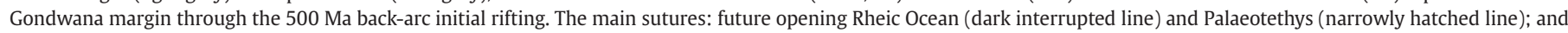

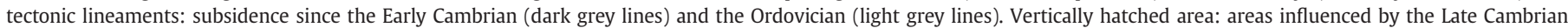

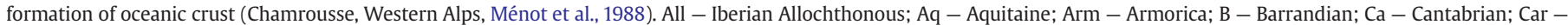
Carnic Alps; CIb - Central Iberia; MC - Massif Central; Ms - Meseta; OM - Ossa Morena; Py - Pyrenees; SX - Saxothuringian; WAL - West Asturian Leonese.

only be guided by the hitherto applied models (e.g. Winchester et al., 2002; Stampfli and Borel 2004), but should also include possible detrital input from some Asian blocks (Hunia), supposed to have been also located along the Cambrian Gondwana margin (Fig. 1). Comparing the localities along the Gondwana margin (Figs. 1 and 2), different palaeogeographic models can be distinguished through the quantity and nature of sediments accumulated in the sedimentary troughs. Consequently, the Gondwana margin can be subdivided into a more western domain, where the future Avalonian blocks will be separated from Gondwana by the opening Rheic Ocean; the Iberian allochthonous units may have been part of the Avalonian domain (compare Arenas et al., 2007a), as well as the Sehoul in Morocco (Hoepffner et al., 2005). In contrast, the more eastern continuation of the converging margin hosts the future basement areas of Central Europe, in which different periods of crustal extension should be distinguished.

\subsection{Cambrian}

The above presented subsidence patterns and the contemporaneous evolution of major structures constrain a plate-tectonic model for the evolution of the Gondwana margin (Figs. 2 and 7). The Neoproterozoic-earliest Cambrian active margin setting of many periGondwana-derived terranes was subsequently replaced by widespread Early Cambrian extension over wide areas of the Gondwana margin. Instead of a simple cylindrical evolution with little or no along-strike variation, it is supposed that crustal extension during the Lower Cambrian followed a more complex pattern with local backarcs and isolated intra-continental rifts (comp. Fig. 2), attaining, still during the Early Cambrian, the stage of carbonate platform evolution.

A subsequent major event is recognized at $500 \mathrm{Ma}$ (comp. Figs. 1, 2 and 7), which, for the eastern regions, corresponds to the formation of oceanic crust of the Chamrousse area (Belledonne massif, Western Alps; Ménot et al., 1988), an event which may correspond, along-strike to the east to mafic-ultramafic bodies in the Saxothuringian and related klippen (Vesser area, Kemnitz et al., 2002; Erbendorf-Hohenstrauss and Münchberg Klippe, Franke, 1995) and the Bohemian Massif (Marianske Lasné Complex, Timmermann et al., 2006). In the Bohemian Massif, Floyd et al. (2000) and Crowley et al. (2002) interpreted the Cambrian continental break-up as a consequence of interaction with a mantle-plume. Upper Cambrian rifting is also reported from the more western continuation in 


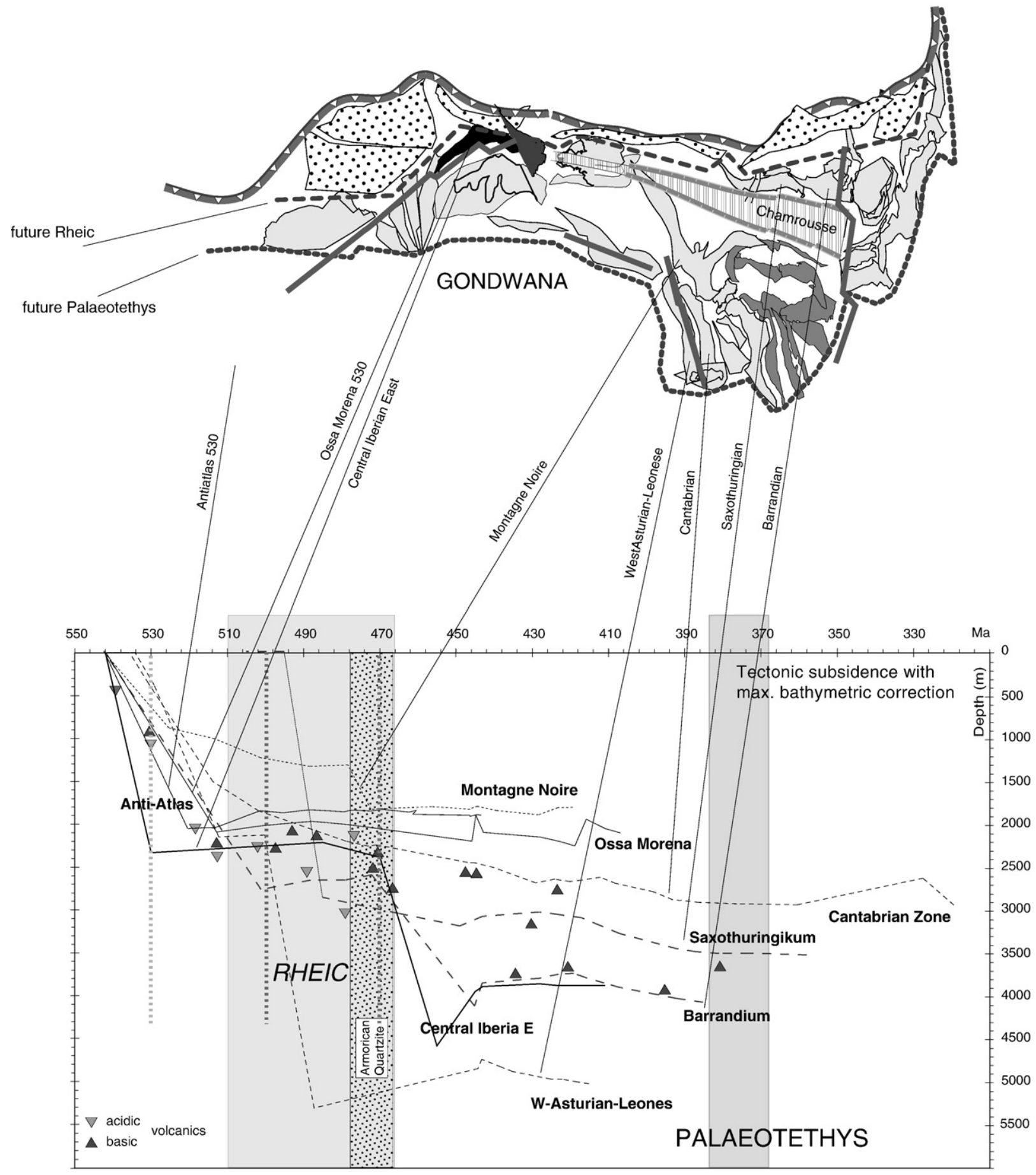

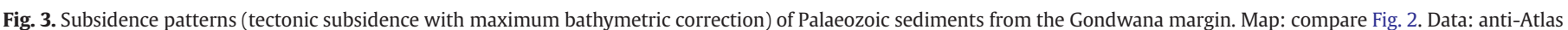

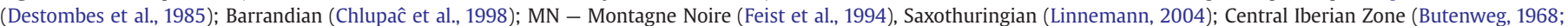

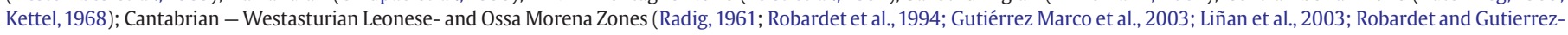
Marco, 2004).

the Massif Central domain, (Limousin area, Pin and Marini, 1993; Briand et al., 1995; Berger et al., 2005). The Upper Cambrian oceanisation of some marginal basins in a context of back-arc rifting, scattered through the Iberian Allochthonous (Arenas et al., 2007a,b) and the formerly nearby areas of rifting like the Ossa Morena Zone (Sánchez García et al., 2003; Quesada, 2006) could equally represent the westward continuation of the Chamrousse Zone, if a more cylindrical model is applied for the Gondwana margin. The location of the Central Iberian Allochthonous and the Ossa Morena Zone were equally near to Cambrian subduction and Cambrian rifting (Figs. 1 and 2). The parallels of sedimentological and volcanic evolution during the Cambrian do not necessarily exclude some freedom in placing Ossa Morena and the Iberian Allochthonous domains along the Gondwana margin. The rather comparable subsidence between the eastern Central Iberian Zone and the Barrandian (Fig. 3) suggests at least the possibility, that both areas had also a comparable location along the Gondwana margin.

How to reconcile this Late Cambrian extension in a general frame? The formation of a large volcanic arc with intrusion of subvolcanic 


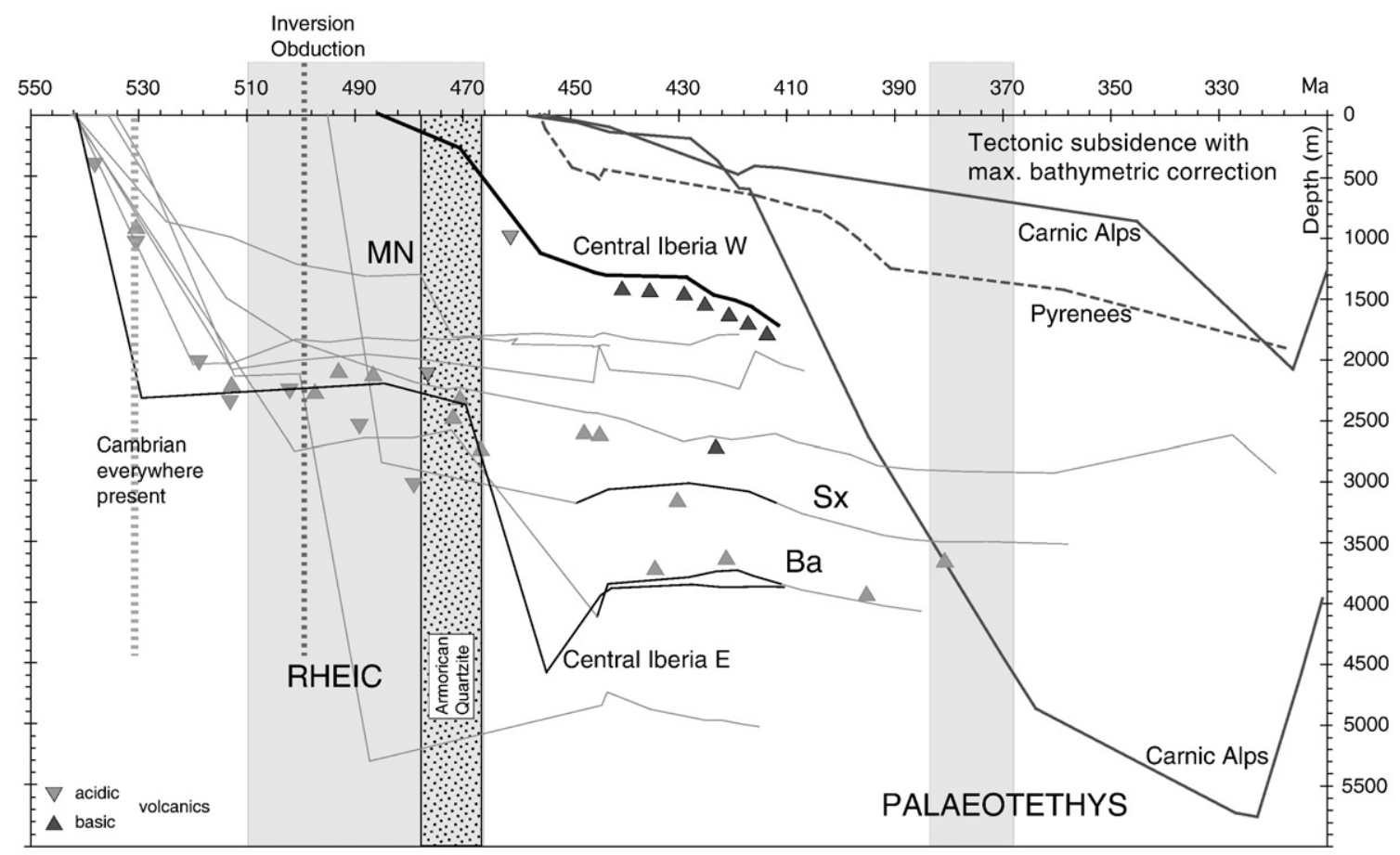

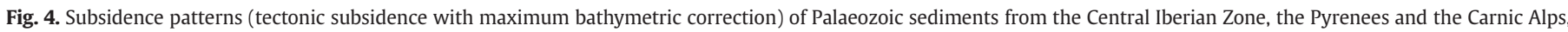

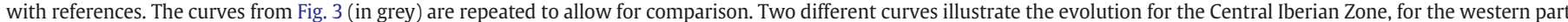

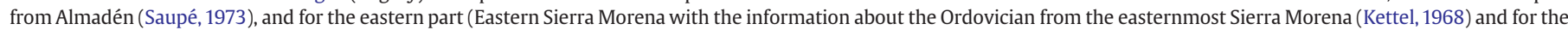

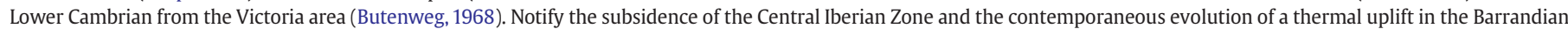

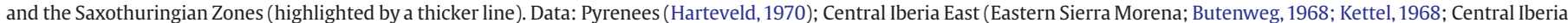
West (Almadén, Saupé, 1973); Carnic Alps (Schönlaub, 1993), other references in Fig. 3.

bodies (Ollo do Sapo, Díez Montes, 2007) and the contemporaneous back-arc opening of the future Rheic Ocean is discussed for the NWIberian Gondwana margin (Arenas et al., 2007b). In applying a model of extending crust, evolving from initial transtension to simple shear extension (Stampfli et al., 1991), we related (Stampfli et al., 2002) the Upper Cambrian granite and gabbro intrusions of the Allochthonous units in NW Spain, accompanied by granulite facies metamorphism and anatexis (Abati et al., 1999), to extensional processes leading to the initial opening and rifting of the Rheic Ocean. Considerable crustal events must have accompanied this evolution and, in Fig. 4, we interpret this short time period as a time of crustal inversion, perhaps accompanied by obduction. Interestingly, Linnemann et al. (2004) discuss the Upper Cambrian inversion of a former rift basin with intrusion of Cambro-Ordovician granitoids. Since our discussion of Cambrian granitoids at the eastern Gondwana margin (von Raumer et al., 2002, 2003), new data confirm the general picture of Late Cambrian crustal extension (Creta, Romano et al., 2004; Turkey (Ustaömer et al., 2005).

The same geodynamic scenario cannot be applied to the entire margin. The ocean opening between Avalonia and Gondwana is usually named Rheic (Fig. 5), and Prigmore et al. (1997) attributed the Late Cambrian-Tremadoc or the Arenig-Llanvirn periods of rifting to the separation of Avalonia from Gondwana. However, Avalonia did not extend along the length of the margin. The eastern continuation of the Rheic Ocean, opening north of the Galatian terranes and separating a ribbon continent (Hunia) represents the eastern branch of the Rheic Ocean (Fig. 5). The Hunia ribbon continent later accreted to the Tarim-North China block, whereas Avalonia accreted to NorthAmerica-Baltica. Eastward, on the Galatian transect (Fig. 7), the Cambrian basins closed during a mid-Ordovician tectonic event (Biino, 1994; Oberli et al., 1994; Schaltegger et al., 2003; Franz and Romer, 2007) that we attribute to the diachronous subduction of the Prototethys mid-ocean ridge. The Hunia terrane can only be detached from Gondwana after this event, through renewed roll-back of the Prototethys sea-floor and total subduction of its mid-oceanic ridge.

The question arises, if the Rheic Ocean opened 470-460 Ma years ago (comp. Prigmore et al., 1997), leading to the separation of the Avalonian terrane, or if the Rheic opened already during the preceding Upper Cambrian opening of a back-arc basin and drifting of the Gander terranes in Upper Cambrian times (comp. discussion in Arenas et al., 2007a, p.29)? We follow the idea that the Gander terrane was most likely detached when Avalonia was already drifting from Gondwana (Valverde-Vaquero et al., 2003), not before, due to accelerating roll-back of the Iapetus Ocean.

\section{From Gondwana to Palaeotethys}

\subsection{The Ordovician period}

It was only after the onset of sea-floor spreading and the consequent drift of Avalonia and Hunia, that the Armorica/Cadomian terranes and the more easterly Intra-Alpine blocks followed an independent platetectonic evolution. Faunal distributions from the time of formation of the Rheic Ocean to the Devonian marine areas characterize the continuous evolution of faunal provinces from the Ordovician to the Devonian (Robardet, 2002, 2003; Fortey and Cocks, 2003). The many Early Palaeozoic, mostly detrital, sediments from Armorica/Cadomia carry benthic faunas and shallow-shelf lithofacies indicating that the underlying continental structures were not separated from the main Gondwana continent by a wide ocean (Robardet, 2002). The model using just one intervening ocean, the Rheic Ocean, rather than postulating several oceanic regions, thus seemed the most economical way to explain the interaction of continental plates. However, whilst accepting these observations and criteria, the solely palaeontological criteria and the construction of biogeographic maps do not prove that there was a stable tectonic shelf, since an epicontinental sea opening 


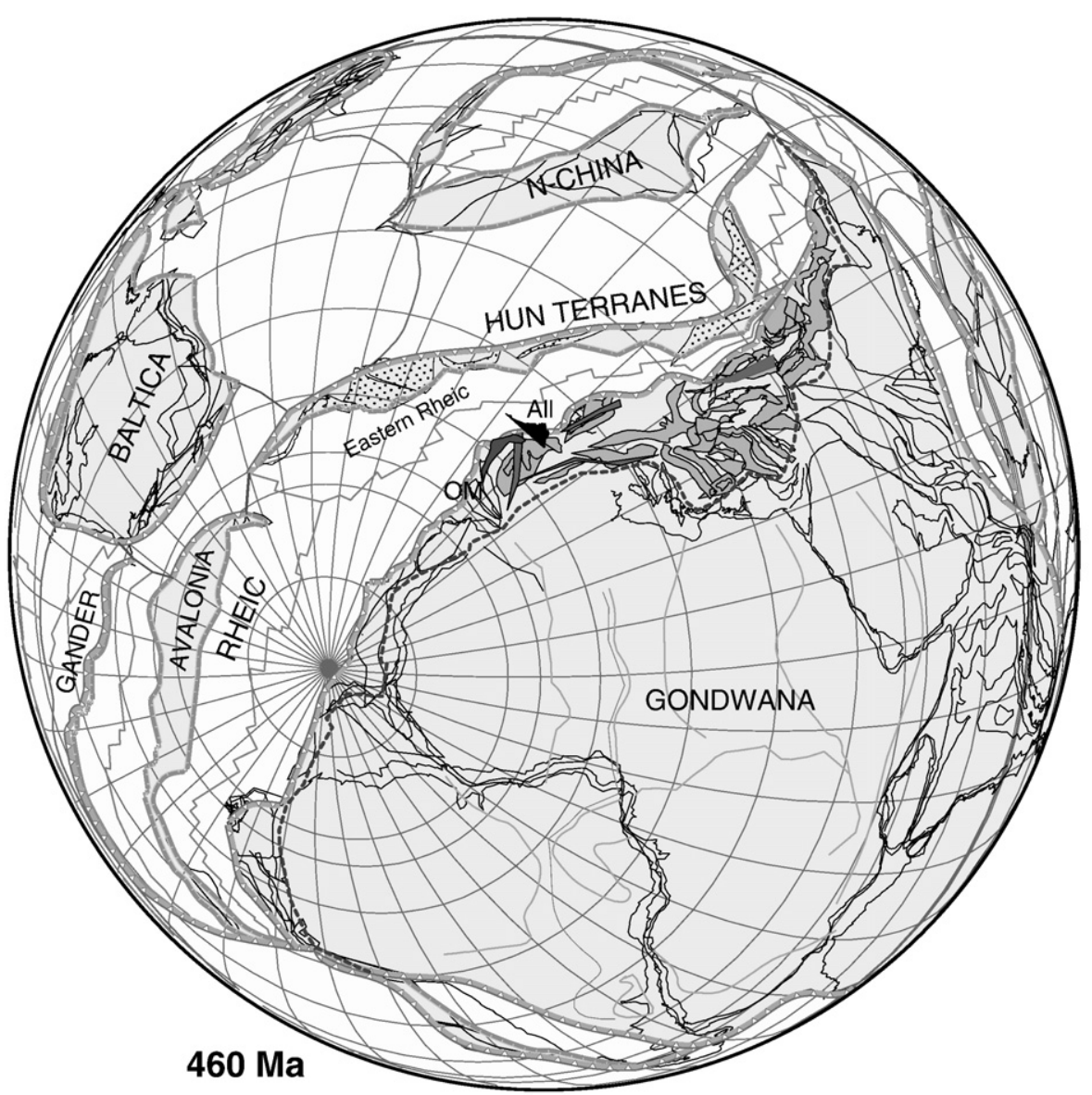

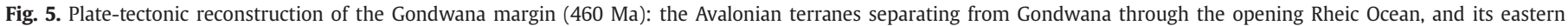

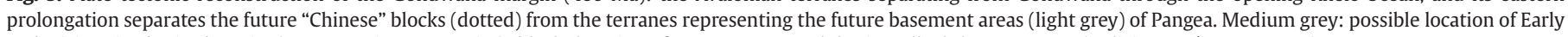
Ordovician rim-basin deposits (e.g. Armorican Quartzite); black: location of Ossa Morena and Iberian Allochthonous areas (Galicia - Trás-os-Montes).

through crustal thinning would also carry a comparable evolution of sediments with identical faunas.

\subsubsection{Sediments and tectonics}

The stronger subsidence since the Ordovician, visible in the corresponding patterns (Figs. 3 and 4), can be explained by the continuation of rifting, and the reworking of the rift shoulders generating voluminous detritus (Armorican Quartzite). The detrital zircons indicate sediment derivation from a wide hinterland (e.g. Martínez Catalán et al., 2004; Drost et al., 2004) into a rim-basin, located at the southern rim of the Cambrian rift system (comp. Fig. 7D). The regional transgression of the Lower Ordovician is documented in Southern Brittany (Robardet et al., 1994; Robardet, 2002, area 1, Fig. 6), and in the Central Iberian domain (Gutierrez Marco et al., 1990; Martínez Catalán et al., 2004; Fig. 6), and subsidence (Figs. 3 and 4) was accompanied by strong volcanic activity. In the Saxothuringian (Fig. 6), the subsidence (compare Figs. 3 and 4) indicates a new rift phase (erosion, denudation), with transgression of the Ordovician on Cambrian sediments or Cadomian basement (comp. Linnemann and Buschmann, 1995). Extension was accompanied by large-scale volcanic activity and thermal uplift (Figs. 3 and 4 ) in the Saxothuringian and the Barrandian areas (area 5, Figs. 6, 3 and 4). This Ordovician phase of extension heralded the opening of Palaeotethys, but its location in an already thinned lithosphere resulted in a less evident subsidence pattern.

\subsubsection{Magmatic evolution}

The Ordovician rifting period is underlined by a strong magmatic activity at the level of the lower crust. Since our comprehensive discussion on Ordovician granitoids (von Raumer et al., 2002; von Raumer et al., 2003) and their narrow relation to Ordovician subduction and subsequent crustal extension, new data are at disposal from different Alpine realms (Bertrand et al., 2000; Guillot et al., 2002; Schulz and Bombach, 2003), from the Carpathian mountains (Gaab et al., 2005), from Sardinia (Helbing 2003; Helbing and Tiepolo 2005; Giacomini et al., 2006), from Sicily (Trombetta et al., 2004), from the Pyrenees (Deloule et al., 2002) and from the Bohemian Massif (Bavarian Forest, Teipel et al., 2004).

Equally, the contemporaneous (460 Ma) gabbroic intrusions in the External Alpine massifs (Paquette et al., 1989; Oberli et al., 1994; Abrecht et al., 1995; Rubatto et al., 2001) and the Austroalpine Silvretta Massif (Poller, 1997) plead for a major crustal event along the eastern part of the Gondwana margin.

\section{Hirnantian glaciation and Silurian crustal extension}

In the Late Ordovician, many areas were covered by the detrital sediments of the Hirnantian glaciation (e.g. Hamoumi 1999; Monod et al., 2003) and, consequently, the future terranes building up Pangea were still located at rather high southern longitudes. The contemporaneous thermal expansion could explain local unconformities or sedimentary gaps, and the rift shoulders may have been the site of ice sheets (e.g. in the Taurus Mountains of Turkey, Monod et al., 2003), whereas in the grabens, graptolite-bearing black-shales were preserved which would otherwise have been eroded. The still epicontinental marine areas allowed the free migration of faunas and, depending on latitude, the passive margins, from the Upper Silurian onwards, were colonised by platform carbonates as the whole area drifted generally northwards (Cocks and Torsvik, 2002). 


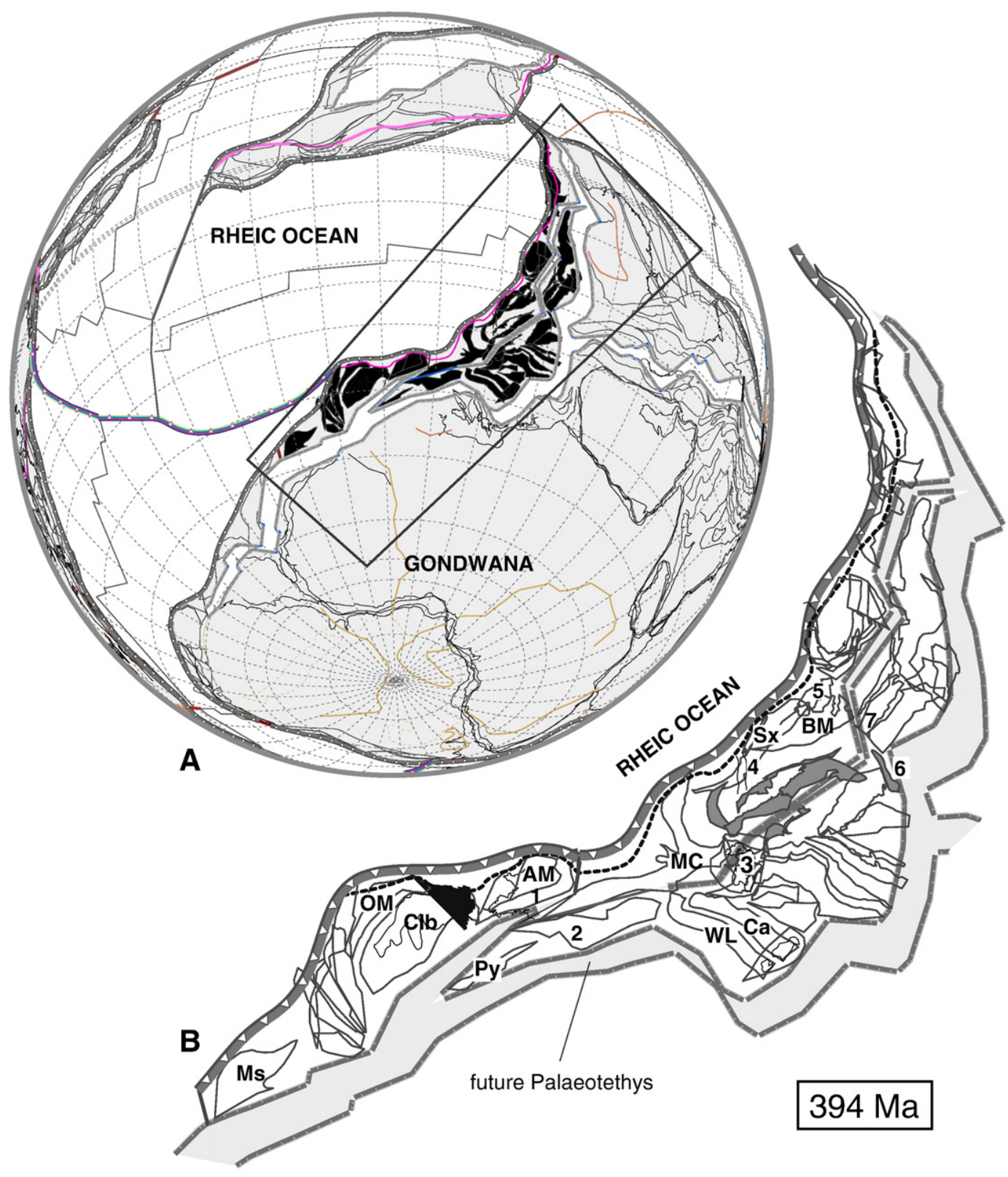

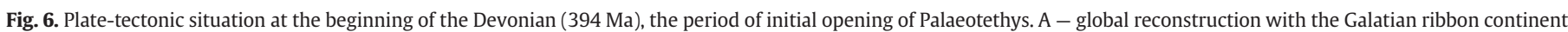

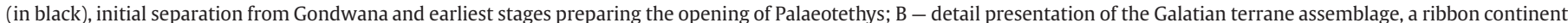

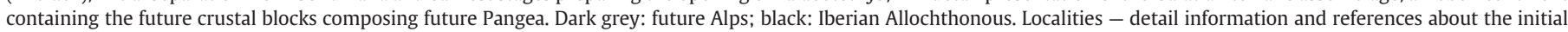

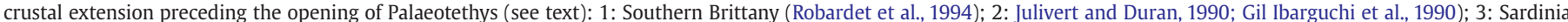

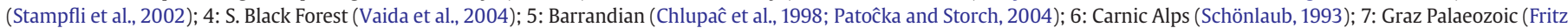

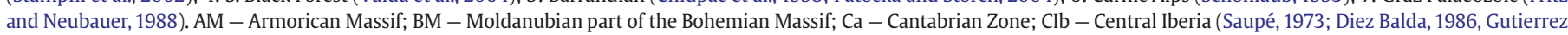

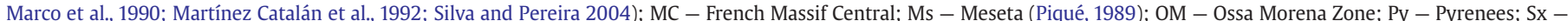
Saxothuringian (Linnemann et al., 2003); WL - Westasturian Leonese Zone.

Transtensive extension with syn-rift volcanism during the Ashgill is observed in the Armorican domain (Chateaulin, Normandie, Robardet et al., 1994), in the Central Iberian domain (Almadén, Gutiérrez Marco et al., 1990; Saupé, 1973), in the Catalonian coastal ranges (locality 2, Fig. 6; Julivert and Duran, 1990; alkaline volcanics, Gil Ibarguchi et al., 1990), in the Prague-basin (Barrandian) of the Bohemian Massif (Patoĉka and Storch, 2004), in Sardinia (flood basalts, Stampfli et al., 2002), and in Iran (flood basalts of up to $500 \mathrm{~m}$ thick extending over $1000 \mathrm{~km}$ of the margin; Bagheri and Stampfli, 2008). In the Eastern Alps (7, Fig. 6; Palaeozoic of Graz, Fritz and Neubauer, 1988), intra-continental alkaline volcanics of Silurian age with subsequent accumulation of siliciclastics in an extensional regime are observed. Silurian "vertical tectonics in a distensive environment (Pieren, 1986 in: Gutiérrez Marco et al., 1990), observed at the southern margin of the central Iberian domain, yielded $\mathrm{Ar}^{40}$ / $\mathrm{Ar}^{39}$ cooling ages of 420-423 Ma (Dallmeyer and Pieren, 1987, recalculated 1989) indicating a contemporaneous metamorphic event in the Precambrian basement. Deposition of volcanosedimentary interbeds and peralkaline volcanics accompany these tectonic events (Diez Balda, 1986; Saupé, 1973). Saupé (1973) argues for an epicontinental environment with shallow basins and ridges, and Diez Balda (1986) describes the extrusion of alkaline basanites, containing breccia and vesicles. In addition, at the northern limit of the Central Iberian domain, Silurian extensional faults strongly influenced the distribution of Silurian sediments (Martínez Catalán et al., 1992, 2004). 


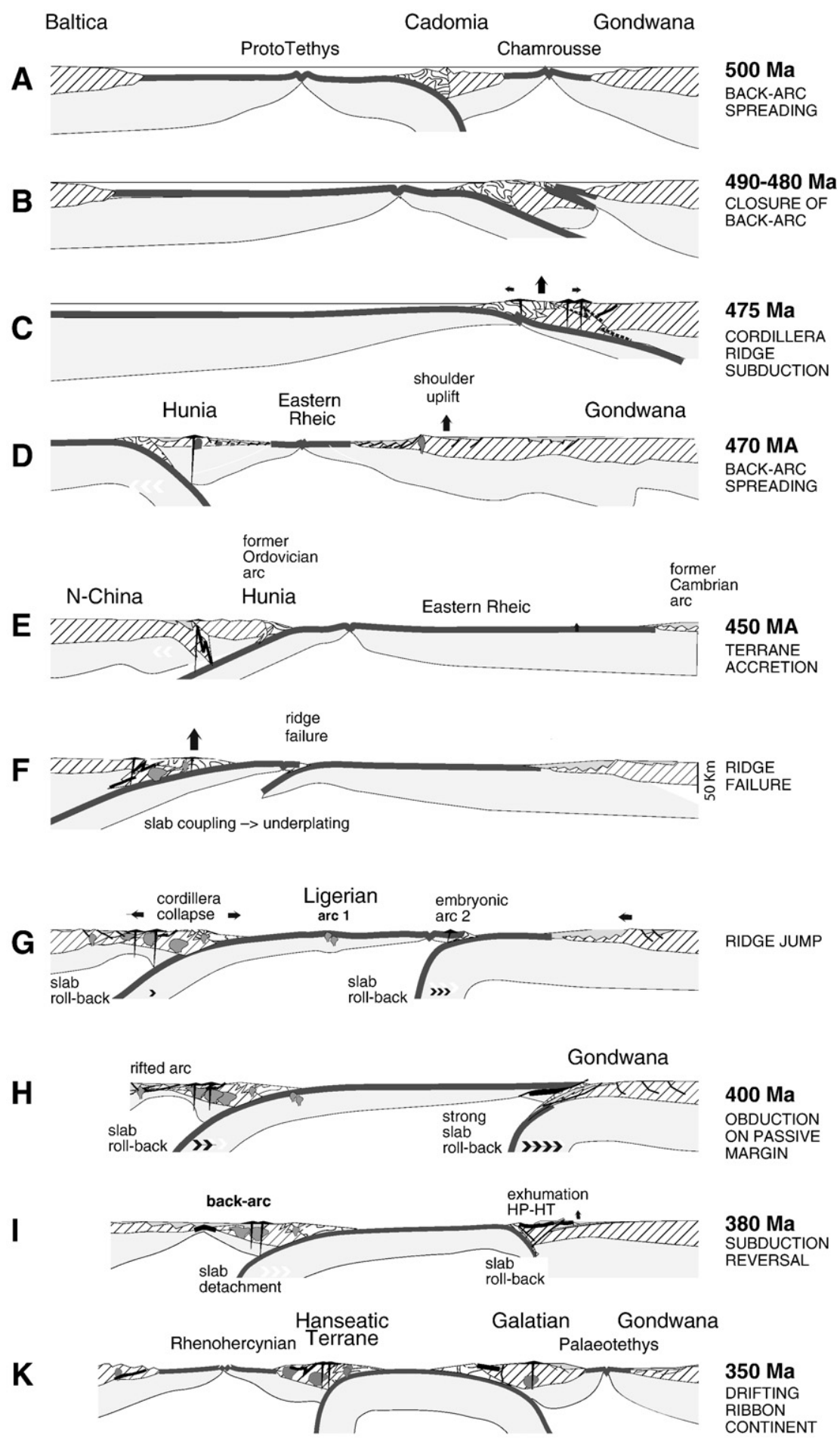

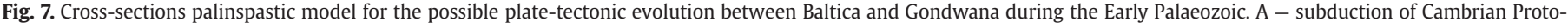

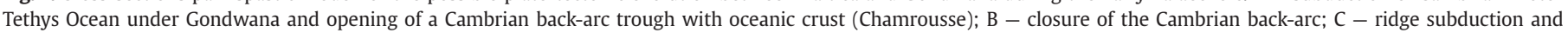

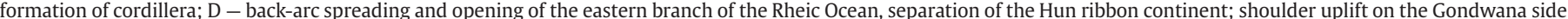

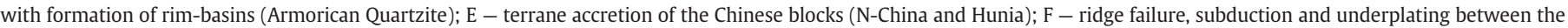

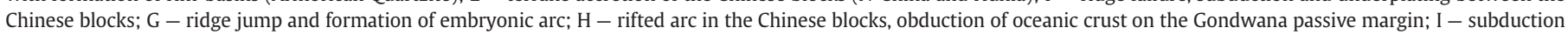
reversal, exhumation of HP-HT units on the Gondwana side; K - opening of Palaeotethys with separation of the Galatian terranes; opening of the Rhenohercynian Ocean.

Among the various sedimentary basins formed since the Ordovician, the Barrandian and Saxothuringian domains were probably part of the northern margin of Palaeotethys before the lateral displacement of the Moldanubian zone to the south of the Saxothuringian Zone. Following the re-interpretation by Stampfli et al. (2002), its autochthonous sequence (Falk et al., 1995) is marked by basin deepening in Silurian times, accompanied by lavas and tuffs in the Ludlow representing the syn-rift event, whereas pelagic Gedinnian to Givetian sediments represent the drift sequence (compare Linnemann, 2004).

Equally, the Central Iberian Zone with its well-known Cambrian to Silurian stratigraphy (Figs. 3 and 4) was the place of tectonic events 
which indicate the initial opening of Palaeotethys. Admittedly, the primary location of the Central Iberian domain together with its adjacent areas may have been very different before the Variscan orogenic events. The sedimentary basins constituting the Lower Palaeozoic cover series in the Eastern Alps represented the northern margin of Palaeotethys. They contain acidic volcanics among Lower Palaeozoic sediments (Loeschke and Heinisch, 1993) with a welldocumented sedimentary evolution (Schönlaub and Heinisch, 1993; Schönlaub and Histon, 2000), representing a rifting environment since the Late Ordovician (Neubauer and von Raumer, 1993; Neubauer and Sassi, 1993). In contrast, the southern passive margin of Palaeotethys is located in the Iranian occurrences, and a similar evolution is found in the Cimmerian part of Turkey (references in Stampfli and Kozur, 2006), and North Africa. In this context, the Moroccan Central Meseta represents the northern margin of Palaeotethys, and was detached from Gondwana together with the Galatian terrane. A syn-rift sequence of Silurian-Lower Devonian age precedes the establishment of a large Devonian carbonate platform related to the drift sequence (Hoepffner et al., 2005). The eastern zone with its totally different stratigraphic record did not belong to the Galatian terrane, but was most likely located to the north of it. The Anti-Atlas formed the southern margin of Palaeotethys.

Concluding, the Gondwana margin had been a passive margin since rifting away of the Hunia terrane, but this evolution failed in some areas due to the Silurian collision (Eo-Variscan phase, see Stampfli et al., 2002 for references) of an intra-oceanic arc with the eastern portion of the Gondwana margin, which took place between 400 and $380 \mathrm{Ma}$ (Fig. 7H). The colliding arc and related obduction developed in the oceanic space that opened between Hunia and Gondwana, The traces of the obducted ophiolite can be found in Spain (e.g. Ordenes complex), France (Champtoceaux complex) and Germany (Münchberg Klippe) and surrounding areas. As the ophiolite obduction is regarded as a hallmark of the outer margin of the Galatian terrane (Fig. 6), this ophiolite belt was used to reconstruct the Galatian terrane geometry (Stampfli et al., 2006). The ophiolite obduction event is not known at the southern margin of the Rheic ocean s.str., preserved in the north and central American terranes, that were later accreted to Laurentia.

Subduction inversion following obduction, inducing opening of Palaeotethys in Upper Devonian times, gave rise to the $10,000 \mathrm{~km}$ long Greater Galatian superterrane (Fig. 6). Apparently the opening of Palaeotethys was nearly synchronous all along the margin but the onset of spreading may have been diachronous, from Middle to late Devonian times.

\section{Acknowledgments}

Part of this manuscript resulted from fruitful exchanges with Robin Cocks (London), reconciling the different ways of thinking about the building up of the Gondwana margin. Many thanks for this patient discussion and collaboration during the early formulation of ideas. We appreciated the help and suggestions of J. J. Alvaro (Lille) and S. Jensen (Badajoz) for finding useful references. The continuous friendly discussion with Ricardo Arenas (Madrid), J. C. Gutiérrez Marco (Madrid), and J. R. Martínez Catalán (Salamanca) is greatly acknowledged. We sincerely thank St. Johnston (Victoria) for his interesting suggestions and his adaptation to a better English version. The interesting remarks and helpful suggestions from two anonymous reviewers were highly appreciated.

\section{References}

Abati, J., Dunning, G.R., Arenas, R., Díaz García, F., Gonzáles Cuadra, P., Martínez Catalán, J.R., Andonaegui, P., 1999. Early Ordovician orogenic event in Galicia (NW Spain): evidence from $\mathrm{U}-\mathrm{Pb}$ ages in the uppermost unit of the Ordenes Complex. Earth and Planetary Science Letters 165, 213-228.
Abrecht, J., Biino, G., Schaltegger, U., 1995. Building the European continent: Late Proterozoic - Early Palaeozoic accretion in the Central Alps of Switzerland. Terra Nova 5 (1), 105 Abstr.

Alvaro, J.J., Elicki, O., Geyer, G., Rushton, A.W.A., Shergold, J.H., 2003. Palaeogeographical controls on the Cambrian trilobite immigration and evolutionary patterns reported in the western Gondwana margin. Palaeogeography, Palaeoclimatology, Palaeoecology 195, 5-35.

The rootless Variscan suture of NW Iberia (Galicia, Spain). The International Geoscience Programme IGCP 497 "The Rheic Ocean: its origin, evolution and correlatives". In: Arenas, R., Martínez Catalán, J.R., Abati, J., Sánchez Martínez, S. (Eds.), Field trip guide Instituto Geológico y Minero de España, Madrid 2007, pp. 1-117.

Arenas, R., Martínez Catalán, J.R., Sánchez Martínez, S., Fernández-Suárez, J., Andonaegui, P., Pearce, J.A., Corfu, F., 2007b. The Vila de Cruces Ophiolite: a remnant of the early Rheic ocean in the Variscan suture of Galicia (northwest Iberian Massif). The Journal of Geology 115, 129-148.

Bagheri, S., Stampfli, G.M., 2008. The Anarak, Jandaq and Posht-e-Badam metamorphic complexes in central Iran: new geological data, relationships and tectonic implications. Tectonophysics 451, 123-145.

Bandres, A., Eguiluz, L., Gil Ibarguchi, J.I., Palacios, T., 2002. Geodynamic evolution of a Cadomian arc region: the northern Ossa-Morena zone, Iberian massif. Tectonophysics $352,105-120$.

Berger, J., Femenias, O., Mercier, J.C.C., Demaiffe, D.J., 2005. Ocean-floor hydrothermal metamorphism in the Limousin ophiolites (western French Massif Central): evidence of a rare preserved Variscan oceanic marker. Metamorphic Geology 23 795-812.

Bertrand, J.M., Pidgeon, R.T., Leterrier, J., Guillot, F., Gasquet, D., Gattiglio, M., 2000 SHRIMP and IDTIMS U-Pb zircon ages of the pre-Alpine basement in the Internal Western Alps (Savoy and Piemont). Schweizerische Mineralogische und Petrographische Mitteilungen 80, 225-248.

Biino, G., 1994. The pre-Late Ordovician metamorphic evolution of the GotthardTavetsch massifs (Central Alps): from Lawsonite to kyanite eclogite to granulite retrogression. Schweizerische Mineralogisch Petrographische Mitteilungen 74, 87-104.

Briand, B., Bouchardon, J.L., Ouali, H., Piboule, M., Capiez, P., 1995. Geochemistry of bimodal amphibolitic - felsic gneiss complexes from eastern Massif Central, France. Geological Magazine 132, 321-337.

Butenweg, P. 1968: Geologische Untersuchungen im Ostteil der Sierra Morena nordöstlich von La Carolina (Prov. Jaén, Spanien). Münstersche Forschungen zur Geologie und Paläontologie 6, 1-126, 61 Fig., 2 Ann., Münster 1968.

Chen, F., Hegner, E., Todt, W., 2000. Zircon ages and Nd Isotopic and chemical compositions of orthogneisses from the Black Forest, Germany: evidence for a Cambrian magmatic arc. International Journal of Earth Sciences 88, 791-802.

Chlupaĉ, I., Havliĉek, V., Kriz, J., Kukal, J., Storch, P., 1998. Palaeozoic of the Barrandian (Cambrian to Devonian). Czech Geological Survey, Prague. 183 p.

Cocks, L.R.M., Torsvik, T.H., 2002. Earth geography from 500 to 400 million years ago: a faunal and palaeomagnetic review. Journal of the Geological Society of London 159, 631-644.

Courjault-Radé, P., Debrenne, F., Gandin, A., 1992. Palaeogeographic and geodynamic evolution of the Gondwana continental margins during the Cambrian. Terra Nova 4 657-667.

Crowley, Q.G., Floyd, P.A., Stedra, V., Winchester, J.A., Kachlik, V., Holland, J.G., 2002. The Marianske-Lazne Complex, NW Bohemian Massif: development and destruction of an Early Palaeozoic seaway. In: Winchester, J.A., Pharaoh, T.C., Verniers, J. (Eds.), Palaeozoic Amalgamation of Central Europe. Gcological Society. London. Special Publications, vol. 201, pp. 177-195.

Dallmeyer, R.D., \& Pieren, A.P., 1987. Evidences of Late Proterozoic tectonometamorphic events In SW Iberia. Significance and palaeogeographic implications., IGCP 233 Nouakchott meeting, Abstr. volume pp. 73-76.

Deloule, E., Alexandrov, P., Cheilletz, A., Laumonier, B., Barbey, P., 2002. In-situ U-Pb zircon ages for Early-Ordovician magmatism in the eastern Pyrenees, France: the Canigou orthogneisses. International Journal of Earth Sciences 91, 398-405.

Destombes, J., Holland, H., Willefert, S., 1985. Lower Palaeozoic rocks of Morocco. In: Holland, C. (Ed.), Lower Palaeozoic Rocks of Northwestern and West-Central Africa. Wiley, N.Y, pp. 91-336.

Diez Balda, M.A., 1986. El complejo esquisto-grauwáquico; las series paleozóicas; la estructura hercinica al sur de Salamanca. Acta Salmanticensia 52, 1-162.

Díez Montes, A., 2007. La Geología del Dominio "Ollo de Sapo" en las comarcas de Sanabria y Terra do Bolo. Laboratorio Xeolóxico de Laxe, Serie Nova Terra, 34, 494 pp.

Dörr, W., Zulauf, G., Fiala, J., Franke, W., Vejnar, Z., 2002. Neoproterozoic to Early Cambrian history of an active plate margin in the Tepla-Barrandian unit - a correlation of U-Pb isotopic - dilution-TIMS ages (Bohemia, Czech Republic). Tectonophysics 352, 65-85.

Drost, K., Linnemann, U.Z., McNaughton, N., Fatka, O., Kraft, P., Gehmlich, M., Tonk, C., Marek, J., 2004. New data on the Neoproterozoic - Cambrian geotectonic setting of the Tepla-Barrandian volcano-sedimentary successions: geochemistry, $\mathrm{U}-\mathrm{Pb}$ zircon ages, and provenance (Bohemian Massif, Czech Republöik). International Journal of Earth Sciences 93, 742-757.

Extebarria, M., Chalot-Prat, F., Apraiz, A., Eguiluz, L., 2006. Birth of volcanic passive margin in Cambrian time: Rift paleogeography of the Ossa-Morena zone. Precambrian Research 147, 366-386.

Falk, F., Franke, W., Kurze, M., 1995. Chapter V.B.1 Stratigraphie. In: Dallmeyer, R.D., Franke, W., Weber, K. (Eds.), Pre-Permian Geology of Central and Eastern Europe Springer Verlag, Berlin Heidelberg New York, pp. 221-234.

Feist, R., Echtler, H., Gautier, J., Mouthier, B., 1994. Biostratigraphy and dynamics of the nonmetamorphic sedimentary record. In: Keppie, J.D. (Ed.), Pre-Mesozoic Geology in France. Springer, Berlin-Heidelberg-New York, pp. 289-304. 
Fernández-Suárez, J., Gutíerrez-Alonso, G., Jenner, G.A., Tubrett, M.N., 2000. New ideas on the Proterozoic - Early Palaeozoic evolution of NW Iberia: insights from U-Pb detrital zircon ages. Precambrian Research 102, 185-206.

Ferrari, O.M., Hochard, C., Stampfli, G.M., 2008. An alternative plate tectonic model for the Palaeozoic-Early Mesozoic Palaeotethyan evolution of Southeast Asia (Northern Thailand-Burma). Tectonophysics 451, 346-365.

Floyd, P.A., Winchester, J., Seston, R., Kryza, R., Crowley, Q.G., 2000. Review of geochemical variation in Lower Palaeozoic metabasites from the NE Bohemian Massif: intracratonic rifting and plume-ridge interaction. In: Franke, W., Altherr, R., Haak, V., Oncken, O., Tanner, D. (Eds.), Orogenic Processes - Quantification and Modelling in the Variscan Belt of Central Europe. Geological Society, London, Special Publications, vol. 179, pp. 155-174.

Fortey, R.A., Cocks, L.R.M., 2003. Palaeontological evidence bearing on global Ordovician-Silurian continental reconstructions. Earth-Science Reviews 61, 245-307.

Franke, W., 1992. Phanerozoic structures and events in Central Europe. In: Blundell, D., Freeman, R., Mueller, St. (Eds.), A Continent Revealed. Cambridge University Press, Cambridge, pp. 164-180.

Franke, W., 1995. Chapter: stratigraphy, structure, and igneous activity. In: Dallmeyer, R.D. Franke, W., Weber, K. (Eds.), Pre-Permian Geology of Central and Eastern Europe. Springer, pp. 277-294.

Franz, L., Romer, R.L., 2007. Caledonian high-pressure metamorphism in the StronaCeneri-Zone (Southern Alps of southern Switzerland and northern Italy). Swiss Journal of Geosciences 100, 457-467.

Fritz, H., Neubauer, F., 1988. Geodynamic aspects of the Silurian and Early Devonian sedimentation in the Paleozoic of Graz (Eastern Alps). Schweizerische Mineralogische und Petrographische Mitteilungen 68, 359-367.

Gaab, A.S., Poller, U., Janak, M., Kohut, M., Todt, W., 2005. Zircon U-Pb geochronology and isotopic characterization for the pre-Mesozoic basement of the Northern Veporic Unit (Central Western Carpathian, Slovakia). Schweizerische Mineralogische und Petrographische Mitteilungen 85, 69-88.

Giacomini, F., Bomparola, R.M., Ghezzo, Cl., Guldbransen, H., 2006. The geodynamic evolution of the southern European Variscides: constraints from the $\mathrm{U} / \mathrm{Pb}$ geochronology and geochemistry of the lower Palaeozoic magmatic-sedimentary sequences of Sardinia Italy). Contributions of Mineralogy and Petrology 152, 19-42.

Gil Ibarguchi, J.I., Navidad, M., Ortega, L.A., 1990. Ordovician and Silurian igneous rocks and orthogneisses in the Catalonian Coastal Ranges. Acta Geologica Hispanica 25 23-29.

Guillot, F., Schaltegger, U., Bertand, J.M., Deloule, E., Baudin, T.H., 2002. Zircon U-Pb geochronology of Ordovician magmatism in the polycyclic Ruitor Massif (Internal Western Alps). International Journal of Earth Sciences 91, 964-978.

Gutiérrez-Alonso, G., Fernández-Suárez, J., Gutiérrez-Marco, J.C., Corfu, F., Murphy, J.B., Suárez, M., 2007. U-Pb depositional age for the upper Barrios Formation (Armorican Quartzite facies) in the Cantabrian zone of Iberia: implications for stratigraphic correlation and paleogeography. In: Linnemann, U., Nance, R.D., Kraft, P., Zulauf, G. (Eds.), The Evolution of the Rheic Ocean: From Avalonian-Cadomian active margin to Alleghenian-Variscan Collision. Geological Society of America Special Paper, vol. 423, pp. 287-296.

Gutiérrez-Marco, J.C., Bernárdez, E., 2003. Un tesoro geológico en la autovía del Cantábrico. Ministerio de Fomento, Madrid. 1-398 pp.

Gutiérrez Marco, J.C., Robardet, M., Rábano, I., Sarmiento, G.N., San José Lancha, M.A. Herranz Araujo, P., Pieren Pidal, A.P., 2003. Ordovician. In: Gibbons, W. \& Moreno, T. (Eds.) The geology of Spain. The Geological Society (Ed.), London, pp. 31-49.

Gutiérrez Marco, J.C., De San Jose, M.A., Pieren, A.P., 1990. Post-Cambrian Palaeozoic stratigraphy. In: Dallmeyer, R.D., Martínez García, E. (Eds.), Pre-Mesozoic Geology of Iberia. Springer, Berlin, pp. 160-171.

Hamoumi, N., 1999. Upper Ordovician glaciation spreading and its sedimentary record in Moroccan North Gondwana margin. Acta Universitatis Carolinae - Geologica 43 111-114.

Harteveld, J.J.A., 1970. Geology of the upper Segre and Valira valleys, Central Pyrenees, Andorra/Spain. Leidse Geologiske Mededelingen 45, 167-236.

Helbing, H., 2003. No suture in the Sardinian Variscides: a structural, petrological, and geochronological analysis. Tübinger Geowissenschaftliche Arbeiten. Reihe A 68,1-190.

Helbing, H. Tiepolo, M., 2005. Age determination of Ordovician magmatism in NE Sardinia and its bearing on Variscan basement evolution. Journal of the Geological Society of London 162,1-12.

Hoepffner, C., Soulaimani, A., Piqué, A., 2005. The Moroccan Hercynides. Journal of African Earth Sciences 43, 144-165.

Julivert, M., Duran, H., 1990. Paleozoic stratigraphy of the central and northern part of the Catalonian Coastal Ranges (NE Spain). Acta Geologica Hispanica 25, 3-12.

Kachlik, V., Patoĉka, F., 1996. Cambrian-Ordovician intracontinental rifting and Devonian closure of the rifting generated basins in the Bohemian Massif realms. Acta Universitatis Carolinae - Geologica 42, 433-441.

Kemnitz, H., Romer, R., Oncken, O., 2002. Gondwana break-up and the northern margin of the Saxothuringian belt (Variscides of Central Europe). International Journal of Earth Sciences 91, 246-259.

Kettel, D., 1968. Zur Geologie der östlichen Sierra Morena im Grenzbereich der Provinzen Jaen Ciudad Real und Albacete (Spanien). Münstersche Forschungen zur Geologie und Paläontologie 8,1-159 Münster.

Kryza, R., Zalaviewicz, J.A., Alexandrowski, P., Sergeev, S., Presnyakov, S., 2007. Ordovician initial-rift volcanism in the Central European Variscides (the Kakzava Mountain, Sudetes, SW Poland): evidence from SIMS dating of zircons. Journal of the Geological Society 164, 1207-1215.

Linnemann, U., 2004. Sedimentation und geotektonischer Rahmen der Beckenentwicklung im Saxothuringikum (Neoproterozoikum - Unterkarbon). Geologica Saxonica 48/49, 71-110.
Linnemann, U., Buschmann, B., 1995. Die cadomische Diskordanz im Saxothuringikum (oberkambrisch-tremadocische overlap-Sequenzen). Zeitschrift der geologischen Wissenschaften 23, 707-727.

Linnemann, U., Gerdes, A., Drost, K., Buschmann, B., 2007. The continuum between Cadomian orogenesis and opening of the Rheic Ocean: constraints from LA-ICP-MS $\mathrm{U}-\mathrm{Pb}$ zircon dating and analysis of plate-tectonic setting (Saxo-Thuringian zone, northeastern Bohemian Massif, Germany). In: Linnemann, U., Nance, R.D., Kraft, P., Zulauf, G. (Eds.), The Evolution of the Rheic Ocean: From Avalonian-Cadomian Active Margin to Alleghenian-Variscan Collision. Geological Society of America Special Paper, vol. 423, pp. 61-96.

Linnemann, U., Elicki, O., Gaitzsch, B., 2003. Die Stratigraphie des Saxothuringikums. Geologica Saxonica 48/49, 29-70.

Linnemann, U., Gehmlich, M., Tichomirova, M., Buschmann, B., Bombach, K., 1998. Tectonostratigraphic events of the Peri-Gondwanan basement of the SaxoThuringian composite terrane (Central European Variscides). Schriften des Staatlichen Museums für Mineralogie und Geologie Dresden 9, 159-161.

Linnemann, U., McNaughton, N.J., Romer, R., Gehmlich, M., Drost, K., Tonk, Ch., 2004. West African provenance for Saxo-Thuringia (Bohemian Massif: Did Armorica ever leave pre-Pangean Gondwana? - U/Pb-SHRIMP zircon evidence and the Ndisotopic record. International Journal of Earth Sciences 93, 683-705.

Liñan, E., Gozalo, R., Palacios, T., Gamez Vintaned, J.A., Ugidos, J.M., Mayoral, E., 2003. Cambrian. In: Gibbons, W., Moreno, T. (Eds.), The Geology of Spain. The Geological Society, London, pp. 17-29.

Liñan, E., Quesada, C., 1990. Rift Phase (Cambrian). In: Dallmeyer, R.D., Martinez Garcia, E. (Eds.), Pre-Mesozoic Geology of Iberia. Springer, Berlin-Heidelberg pp. 259-266.

Loeschke, J., Heinisch, H., 1993. Palaeozoic volcanism of the Eastern Alpsand its palaeotectonic significance. In: von Raumer, J., Neubauer, F. (Eds.), The PreMesozoic Geology in the Alps. Springer, Heidelberg, pp. 441-455.

Martínez Catalán, J.R., Fernandez-Suarez, J., Jenner, G.A., Belousova, E., Diez Montes, A 2004. Provenance constraints from detrital zircon U-Pb ages in the Iberian Massif: implications for Palaeozoic plate configuration and Variscan evolution. Journal of the Geological Society, London 161, 463-476.

Martínez Catalán, J.R., Hacar Rodriguez, M.P., Villar Alonso, P., Perez-Estaún, A., González Lodeiro, F., 1992. Lower Paleozoic extensional tectonics in the limit between the West Asturian-Leonese and Central Iberian Zones of the Variscan fold-belt in NW Spain. Geologische Rundschau 81, 545-560.

Ménot, R.P., Peucat, J.J., Scarenzi, D., Piboule, M., 1988. 496 My age of plagiogranites in the Chamrousse ophiolite complex (external crystalline massifs in the French Alps): evidence of a lower Paleozoic oceanization. Earth and Planetary Sciences Letters 88, $82-92$.

Monod, O., Kozlu, H., Ghienne, J.F., Dean, W.T., Günay, Y., Le Hérissé, A., Paris, F., 2003. Late Ordovician glaciation in southern Turkey. Terra Nova 15, 249-257.

Murphy, J.B., Nance, R.D., 1989. Model for the evolution of the Avalonian-Cadomian belt. Geology 17, 735-738

Murphy, J.B., Gutierrez-Alonso, G., Nance, R.D., Fernandez-Suarez, J., Keppie, J.D., Quesada, C., Strachan, R.A., Dostal, J., 2006. Origin of the Rheic Ocean: rifting along a Neoproterozoic suture? Geology 34, 325-328.

Nance, R.D., Murphy, J.B., Keppie, J.D., 2002. A Cordilleran model for the evolution of Avalonia. Tectonophysics 352,1-21.

Neubauer, F., Sassi, F.P., 1993. The Austroaalpine quartzphyllites and related Palaeozoic formations. In: von Raumer, J., Neubauer, F. (Eds.), The Pre-Mesozoic Geology in the Alps. Springer, Heidelberg, pp. 423-439.

Neubauer, F., von Raumer, J., 1993. The Alpine basement - linkage between Variscides and East-Mediterranean mountain belt. In: von Raumer, J.F., Neubauer, F. (Eds.), The Pre-Mesozoic Geology in the Alps. Springer, Berlin, Heidelberg, pp. 641-663.

Oberli, F., Meier, M., Biino, G., 1994. Time constraints on the pre-Variscan magmatic/ metamorphic evolution of the Gotthard and Tavetsch units derived from singlezircon U-Pb results. Schweiz min petr Mitt 74, 483-488.

Paquette, L., Ménot, R.P., Peucat, J.J., 1989. REE, Sm-Nd and U-Pb zircon study of eclogites from the Alpine External massifs (Western Alps): evidence for crustal contamination. Earth Planet Sci Letters 96, 181-198.

Patoĉka, F., Storch, P., 2004. Evolution of geochemistry and depositional settings of Early Palaeozoic siliclastics of the Barrandian (Tepla-Baranndian Unit, Bohemian Massif, Czech Republic). International Journal of Earth Sciences 93, 728-741.

Pereira, M.F., Silva, J.B., Chichorro, M., Moita, P., Santos, J.F., Apraiz, A., Ribeiro, C., 2007. Crustal growth and deformational processes in the northern Gondwana margin: constraints from the Évora Massif (Ossa-Morena zone, southwest Iberia, Portugal). In: Linnemann, U, Nance, R.D., Kraft, P. Zulauf, G. (Eds.), The Evolution of the Rheic Ocean: From Avalonian-Cadomian Active Margin to Alleghenian-Variscan Collision. Geological Society of America Special Paper, vol. 423, pp. 333-358.

Pieren, A.P. 1986. Mobilité du bassin sédimentaire au Silurien inférieur dans le synclinal de Herrera del Duque (Badajoz, Espana), 11e Réunion des Sciences de la Terre. Abstracts, Clermond-Ferrand, p. 148.

Pin, C. Marini, F., 1993. Early Ordovician continental break-up in Variscan Europe: Nd$\mathrm{Sr}$ isotope and trace element evidence from bimodal igneous associations of the Southern Massif central, France. Lithos 29, 177-196.

Piqué, A., 1989. Variscan terranes in Morocco. Geological Society of America Special Paper 230, 115-129.

Poller, U., 1997. U-Pb single zircon study of gabbroic and granitoid rocks of Val Barlas-ch (Silvretta nappe, Switzerland). Schweiz Min Petr Mitt 77, 351-359.

Prigmore, J.K., Butler, A.J., Woodcock, N.J., 1997. Rifting during separation of Eastern Avalonia from Gondwana. Evidence from subsidence analyses. Geology 25, 203-206.

Putis, M., Sergeev, S., Ondrejkai, M., Larionov, A., Siman, P., Spisiak, J., Uher, P., Paderin, I., 2008. Cambro-Ordovician metaigneous rocks in the West-Carpathian basement dated by SHRIMP: record from the Gondwana riftogeneous margin. Geol. Carpath. 59 (1), 3-18 
Quesada, C., 2006. The Ossa-Morena Zone of the Iberian Massif: a tectonostratigraphic approach to its evolution. Z. dt. Ges. Geowiss 157, 585-595.

Radig, F., 1961. Zur Stratigraphie des Devons in Asturien (Nordspanien). Geologische Rundschau 51, 249-267.

Robardet, M., 2002. Alternative approach to the Variscan Belt in southwestern Europe: preorogenic paleobiogeographical constraints. In: Martínez Catalán, J.R., Hatcher Jr., R.D., Arenas, R., Diaz Garcia, F. (Eds.), Variscan-Appalachian Dynamics: The Building of the Late Paleozoic Basement. Geological Society of America Special Paper, vol. 364 , pp. 1-15.

Robardet, M., 2003. The Armorica "microplate": fact of fiction? Critical review of the concept and contradictory palaeobiogeographical data. Palaeogeography, Palaeoclimatology, Palaeoecology 195, 125-148.

Robardet, M., Verniers, J., Feist, R., Pairis, F., 1994. Le Paléozoïque anté-varisque de France, contexte paléogéographique et géodynamique. Géologie de la France 3, 3-31.

Robardet, M., Gutierrez-Marco, J.C., 2004. The Ordovician, Silurian and Devonian sedimentary rocks of the Ossa-Morena Zone (SW Iberian Peninsula, Spain). Journal of Iberian Geology 30, 73-92.

Rodríguez Alonso, M.D., Peinado, M., López-Plaza, M., Franco, P., Carnicero, A. Gonzalo, J.C., 2004. Neoproterozoic-Cambrian synsedimentary magmatism in the Central Iberian Zone (Spain): geology, petrology and geodynamic significance. International Journal of Earth Sciences 93, 897-920.

Romano, S.S., Dörr, W., Zulauf, G., 2004. Total Pb loss of Cadomian zircons due to Alpine subduction: examples from the pre-Alpine basement of Crete. In: Dörr, W., Finger, F., Linnemann, U., Zulauf, G. (Eds.), The Avalonian-Cadomian Belt and related PeriGondwanan terranes. Int. J. Earth Sci., vol. 93, pp. 844-859.

Rubatto, D., Schaltegger, U., Lombardo, B., Colombo, F., Compagnoni, R., 2001. Complex Paleozoic magmatic evolution in the Argentera Massif(Western Alps) resolved with $\mathrm{U}-\mathrm{Pb}$ dating. Schweizerische Mineralogische und Petrographische Mitteilungen 81, 213-228.

Sánchez García, T., Bellido, F., Quesada, C., 2003. Geodynamic setting and geochemical signatures of Cambrian-Ordovician rift-related igneous rocks (Ossa-Morena Zone, SW Iberia). Tectonophysics 365, 233-255.

Saupé, F., 1973. La géologie du gisement de mercure d'Almadén, Province de Ciudad Real, Espagne. Sciences de la Terre Mémoire 29, 1-342 Nancy.

Schaltegger, U., Abrecht, J., Corfu, F, 2003. The Ordovician orogeny in the Alpine basement: constraints from geochronology and geochemistry in the Aar Massif (Central Alps). Schweizerische Mineralogische Petrographische Mitteilungen 83, 183-195.

Schaltegger, U., Gebauer, D., 1999. Pre-Alpine geochronology of the Central, Western and Southern Alps. Schweizerische Mineralogische und Petrographische Mitteilungen 79, 79-87.

Schaltegger, U., Gebauer, D., von Quadt, A., 2002. The mafic-ultramafic rock association of Loderio-Biasca (lower Pennine Nappes, Ticino, Switzerland): Cambrian oceanic magmatism and its bearing on early Paleozoic paleogeography. Chemical Geology 186, 265-279.

Schaltegger, U., Nägler, Th. N., Corfu, F., Maggetti, M., Galetti, G., Stosch, H., 1997. A Cambrian island arc in the Silvretta nappe: constraints from geochemistry and geochronology. Schweizerische Mineralogische und Petrographische Mitteilungen 77, 337-350.

Schönlaub, H.P., 1993. Stratigraphy, biogeography and climatic relationships of the Alpine Paleozoic. In: von Raumer, J., Neubauer, F. (Eds.), The Pre-Mesozoic Geology in the Alps. Springer, Heidelberg, pp. 65-91.

Schönlaub, H.P., Heinisch, H., 1993. The classic fossiliferous Palaeozoic units of the eastern and southern alps. In: von Raumer, J., Neubauer, F. (Eds.), The Pre-Mesozoic Geology in the Alps. Springer, Heidelberg, pp. 395-422.

Schönlaub, H.P., Histon, K., 2000. The Palaeozoic evolution of the Southern Alps. Mitteilungen der österreichischen geologischen Gesellschaft 92, 15-34.

Schulz, B., Bombach, K., 2003. Single zircon Pb-Pb geochronology in the Austroalpine basement to the south of the Tauern Window. Jahrbuch der Geologischen Bundesanstalt 43, 303-321.

Schulz, B., Bombach, K., Pawlig, S., Brätz, H., 2004. Neoproterozoic to Early-Palaeozoic magmatic evolution in the Gondwana-derived Austroalpine basement to the south of the Tauern Window (Eastern Alps). International Jounral of Earth Sciences 93, 824-843.

Silva, J.B., Pereira, M.F., 2004. Transcurrent continental tectonics model for the OssaMorena Zone Neoproterozoic-Palaeozoic evolution SW Iberian Massif, Portugal. International Journal of Earth Sciences 93, 886-896.

Stampfli, G.M., Borel, G.D., 2004. The TRANSMED transects in space and time: constraints on the paleotectonic evolution of the Mediterranean domain. In: Cavazza, W., Roure, F., Spakman, W., Stampfli, G.M., Ziegler, P. (Eds.), The TRANSMED Atlas: the Mediterranean Region from Crust to Mantle. Springer, Berlin, pp. 53-80.

Stampfli, G.M., Hochard, C., von Raumer, J.F., 2006. Reconstructing the Palaeozoic Gondwana margin and its redistribution - new aspects. Geophys Res. Abs. 8 , EGU06-A-02708 web:unil.ch/igp/page22636.html.

Stampfli, G.M., Kozur, H., 2006. Europe from the Variscan to the Alpine cycles. In: Gee, D.G., Stephenson, R. (Eds.), European Lithosphere Dynamics, 32. Memoirs of the Geological Society, London, pp. 57-83.
Stampfli, G., Marcoux, J., Baud, A., 1991. Tethyan margins in space and time Palaeogeography, Palaeoclimatology, Palaeoecology 87, 373-409.

Stampfli, G.M., Mosar, J., Favre, P., Pillevuit, A., Vannay, J.-C., 2001. Permo-Mesozoic evolution of the western Tethyan realm: the Neotethys/East-Mediterranean connection. In: Ziegler, P.A., Cavazza, W., Robertson, A.H.F.R., Crasquin-Soleau, S. (Eds.), Memoir 6: Peritethyan Rift/Wrench Basins and Passive Margins. Mémoires du Muséum National d'Histoire Naturelle Paris, vol. 186, pp. 51-108.

Stampfli, G.M., von Raumer, J., Borel, G., 2002. The Paleozoic evolution of pre-Variscan terranes: from Gondwana to the Variscan collision. In: Martinez Catalan, J.R. HatcherJr. Jr., R.D., Arenas, R., Diaz Garcia, F. (Eds.), Variscan-Appalachian Dynamics: the Building of the Late Paleozoic Basement. Geological Society of America Special Paper, vol. 364, pp. 263-280.

Stipska, P., Schulmann, K., Thompson, A.B., Jezek, J., Kröner, A., 2001. Thermomechanical role of a Cambro-Ordovician palaeorift during the Variscan collision: the NE margin of the Bohemian Massif. Tectonophysics 332, 239-253.

Teipel, U., Eichorn, R., Loth, G., Rohrmüller, J., Höll, R., Kennedy, A., 2004. U-Pb SHRIMP and $\mathrm{Nd}$ isotopic data from the western Bohemian Massif (Bayerischer Wald Germany): Implications for Upper Vendian and lower Ordovician magmatism. International Journal of Earth Sciences 93, 782-801.

Thöni, M., 1999. A review of geochronological data from the Eastern Alps. Schweizerische Mineralogische und Petrographische Mitteilungen 79, 209-230.

Timmermann, H., Dörr, W., Krenn, E., Finger, F., Zulauf, G., 2006. Conventional and in situ geochronology of the Tepla Crystalline unit, Bohemian massif: implications for the processes involving monazite formation. International Journal of Earth Sciences 95 629-648.

Trombetta, A., Cirrincione, R., Corfu, F., Mazzoleni, P., Pezzino, A., 2004. Mid-Ordovician $\mathrm{U}-\mathrm{Pb}$ ages of porphyroids in the Peloritan Mountains (NE Sicily): palaeogeographical implications for the evolution of the Alboran microplate. Journal of the Geological Society, London 161, 265-276.

Ugidos, J.M., Billström, K., Valladares, M.I., Barba, P., 2003. Geochemistry of the Upper Neoproterozoic and lower Cambrian siliclastic rocks and U-Pb dating on detrital zircons in the Central Iberian Zone, Spain. International Journal of Earth Sciences 92, 661-676.

Ustaömer, P.A., Mundil, R., Renne, P.R., 2005. U-Pb and P-Pb zircon ages for arc-related intrusions of the Bolu Massif (W Pontides, NW Turkey): evidence for Late Precambrian (Cadomian) age. Terra Nova 17, 215-223.

Vaida, M., Hann, H.P., Sawatzki, G., Frisch, W., 2004. Ordovician and Silurian protolith ages of metamorphosed clastic sedimentary rocks from southern Schwarzwald, SW Germany: a palynological study and its bearing on the Early Palaeozoic geotectonic evolution. Geological Magazine 141, 629-643.

Valverde-Vaquero, P., Staal, C.R., van Velden, A., van der Dunning, G.R., 2003. Acadian orogenesis and high grade metamorphism in the Central Mobile Belt of central Newfoundland. - Geol. Soc. America, Northeastern Sect. Ann. Meeting, Abstracts with Programs, 35: 23, Halifax.

Verniers, J., Pharaoh, T., Debacker, T.N., de Vos, W., Everaerts, M., Herbosch, A. Samuelson, J., Sintubin, M., Vecoli, M., 2002. The Cambrian to mid Devonian basin development and deformation history of Eastern Avalonia, east of the Midlands Microcraton: new data and review. In: Winchester, J.A., Pharaoh, T., Verniers, J. (Eds.), Palaeozoic Amalgamation of Central Europe. . Special Publications, vol. 201. Geological Society, London, pp. 47-93.

von Raumer, J.F., Stampfli, G.M., Borel, G.D., Bussy, F., 2002. The organization of preVariscan basement areas at the Gondwana margin. International Journal of Earth Sciences 91, 35-52.

von Raumer, J.F., Stampfli, G.M., Bussy, F., 2003. Gondwana-derived microcontinents the constituents of the Variscan and Alpine collisional orogens. Tectonophysics 365 $7-22$.

von Raumer, J.F., Stampfli, G.M., Hochard, C., Gutiérrez-Marco, J.C., 2006. The Early Palaeozic in Iberia - a plate-tectonic interpretation. Zeitschrift der Deutschen Gesellschaft für Geowissenschaften 157, 575-584.

Winchester, J.A., Pharaoh, T.C., Verniers, J., 2002. Palaeozoic amalgamation of Centra Europe: an introduction and synthesis of new results from recent geological and geophysical investigations. In: Winchester, J.A., Pharaoh, T.C., Verniers, J. (Eds.) Palaeozoic Amalgamation of Central Europe. Geological Society Special Publication, vol. 201, pp. 1-18

Zeh, A., Brätz, H., Millar, I.L., Williams, I.S., 2001. A combined zircon SHRIMP and Sm-Nc isotope study of high-grade paragneisses from the Mid-German Crystalline Rise: evidence for northern Gondwana and Grenvillian provenance. Journal of the Geological Society, London 158, 983-994.

Zulauf, G., Dörr, W., Fiala, J., Vejnar, Z., 1997. Late Cadomian crustal tilting and Cambrian transtension in the Tepla-Barrandian unit (Bohemian Massif, Central European Variscides). Geologische Rundschau 86, 571-584.

Zulauf, G., Schitter, F., Riegler, G., Finger, F., Fiala, J., Vejnar, Z., 1999. Age constraints on the Cadomian evolution of the Tepla Barrandian unit (Bohemian Massif) through electron microprobe dating of metamorphic monazite. Zeitschrift der deutschen geologischen Gesellschaft 150, 627-639. 